\title{
Forest regrowth reduces richness and abundance of invasive alien plant species in community managed Shorea robusta forests of central Nepal
}

\author{
Laxmi Khaniya and Bharat Babu Shrestha* (D)
}

\begin{abstract}
Background: Natural forests are generally considered to be less prone to biological invasions than other modified ecosystems, particularly when canopy cover is high. Few decades of management of degraded forests by local communities in Nepal has increased canopy cover and altered disturbance regimes. These changes might have reduced the abundance of invasive alien plant species (IAPS) in forests. To understand the status of IAPS in such forests, we studied two community managed Shorea robusta forests (Sundari and Dhusheri) of Nawalpur district in central Nepal. In these two forests, vegetation sampling was done using circular plots $10 \mathrm{~m}$ radius at forest edge, gaps, and within canopy. Variation of IAPS richness and cover across these microhabitats were compared, and their variation with tree canopy cover and basal area analyzed.
\end{abstract}

Result: Altogether 14 IAPS were recorded in the study forests; among them Chromolaena odorata, Ageratum houstonianum, and Lantana camara had the highest frequency. Mikania micrantha was at the early stage of colonization in Sundari Community Forest (CF) but absent in Dhuseri CF. Both IAPS cover and richness was higher at forest edge and gap than in canopy plots and both these attributes declined with increasing canopy cover and tree basal area.

Conclusion: The results indicate that increase in canopy cover and closure of forest gaps through participatory management of degraded forests can prevent plant invasions and suppress the growth of previously established IAPS in Shorea robusta forests of Nepal. This is the unacknowledged benefit of participatory forest management in Nepal.

Keywords: Biological invasions, Chromolaena odorata, Community Forests, Ecosystem-based management, Forest canopy gap, Forest edge

\section{Background}

Invasive alien plant species (IAPS) displace native species, reduce biodiversity, alter species composition, and negatively affect tree regeneration in forests (Belnap et al. 2005, Baret et al. 2008, Minden et al. 2010). In addition, they also alter soil microbial community, litter quality, and thus the overall ecosystem functions of the forests

\footnotetext{
* Correspondence: bb.shrestha@cdbtu.edu.np

Central Department of Botany, Tribhuvan University, Kathmandu, Nepal
}

(Ehrenfeld 2003, Martin et al. 2009). Plant invasions occur in forests as a result of human disturbances leading to the formation of canopy gaps (Baret et al. 2008, Burnham and Lee 2010). Disturbances mostly increase resource availability, and facilitate the colonization of such habitats by IAPS which often have higher competitive abilities than the native species (Parendes et al. 2000). Therefore, the IAPS can easily colonize forest gaps and edges by taking advantage of high resources availability including light radiation (Yamamoto 2000, Funk 2013). In canopy gaps,

(c) The Author(s). 2020 Open Access This article is licensed under a Creative Commons Attribution 4.0 International License, which permits use, sharing, adaptation, distribution and reproduction in any medium or format, as long as you give appropriate credit to the original author(s) and the source, provide a link to the Creative Commons licence, and indicate if changes were made. The images or other third party material in this article are included in the article's Creative Commons licence, unless indicated otherwise in a credit line to the material. If material is not included in the article's Creative Commons licence and your intended use is not permitted by statutory regulation or exceeds the permitted use, you will need to obtain permission directly from the copyright holder. To view a copy of this licence, visit http://creativecommons.org/licenses/by/4.0/ 
IAPS dominate the vegetation and may lead to the local extinction of native species (Vargas et al. 2013). Similarly, forest edges trap airborne propagules of IAPS and facilitate invasion (Joshi et al. 2015). Thus, areas with small patches or more edge density are more vulnerable to invasion by IAPS (Mavimbela et al. 2018).

Widespread occurrence of IAPS has become a serious problem for biodiversity conservation and forest management in Nepal (MFSC 2014, Shrestha 2019). The IAPS is spreading into forests under different management regimes such as community managed forests (hereafter referred as community forests, CF), national forests, and those inside protected areas. The CF management has been considered as one of the most successful participatory program for management of degraded forests particularly in hilly regions of Nepal (Shrestha et al. 2010). Although, various aspects of CF management such as carbon stock (Thapa-Magar and Shrestha 2015) and deforestation and poverty reductions (Oldekop et al. 2019) have been explored, the status of the IAPS has been seldom analyzed. Furthermore, IAPS has not been integrated formally in the management plans of CFs and the impacts of CF management on IAPS diversity and abundance remains understudied in Nepal (Shrestha 2019). In this context, we aimed to test hypothesis that IAPS richness and cover decline with increasing tree canopy and basal area in forests, taking two CFs of Nawalpur district as a case. The overall aim of the research is to study the diversity and abundance of IAPS in the two selected CFs and the specific objectives were (1) to carry out the inventory of IAPS in Sundari and Dhuseri CF of Nawalpur district; and (2) to analyze spatial pattern of the distribution of the IAPS in relation to tree canopy cover and tree basal area. The results have direct implications for integrating IAPS management component in the operational management plans of the CFs.

\section{Materials and methods Study area}

The study was carried out in the Nawalpur District, which is located in the south-central part of Nepal. Among the 208 community forests (CF) in the district (personal communication on 4 April 2020 with Hari Gautam, Assistant Forest Officer, Division Forest Office, Nawalpur), two were selected for the present study; they were Sundari CF $\left(27^{\circ} 43^{\prime} 5^{\prime \prime}-27^{\circ} 44^{\prime} 50^{\prime \prime} \mathrm{N}, 84^{\circ} 14^{\prime} 20^{\prime \prime}-84^{\circ} 16^{\prime} 30^{\prime \prime}\right.$ E; elevation 175-365 masl; area $4.038 \mathrm{~km}^{2}$ ) and Dhuseri CF $\left(27^{\circ} 41^{\prime} 20^{\prime \prime}-27^{\circ} 42^{\prime} 60^{\prime \prime} \mathrm{N}, 84^{\circ} 13^{\prime} 10^{\prime \prime}-84^{\circ} 14^{\prime} 15^{\prime \prime}\right.$ 'E; elevation 160-300 masl; $3.847 \mathrm{~km}^{2}$ ) (Fig. 1). These two CFs are among the most effectively managed CF in terms of good governance, poverty alleviation programs, and protection of the forests. They also have the longest history (> 30 years) of participatory forest management in Nawalpur district. Both these forests are located in the foothill of
Mahabharat range with slope 0-40 (DCFUG 2007, SCFUG 2007). They were handed officially to the local communities (called Community Forest Users' Group) for management as "community forest" by then District Forest Office in 1996 but communities started conservation of forest several years before the official handover.

Before community management was initiated, both forests were highly degraded (personal communication with Chakra Mani Khanal and Indra Prashad Adhikari, Nawalpur District, January 2016). There were 1219 user households of Sundari CF and 829 households of Duseri CF. Communities were allowed to collect firewood and fodder under certain regulations but livestock grazing has been prohibited. As a part of management, silvicultural activities were undertaken that included clearing ground vegetation (including weeds), pruning, thinning, and singling. These tasks have been done every year from October to December. To guide the forest management activities, each forest has operational plan that was approved by District Forest Office. Management of IAPS has not been included in these operational plans.

The study area has dry subtropical climate. The average annual precipitation is $2388 \mathrm{~mm}$, with nearly $80 \%$ precipitation occurring during monsoon which lasts from June to August. The mean maximum temperature is $31{ }^{\circ} \mathrm{C}$ and minimum temperature $19{ }^{\circ} \mathrm{C}$. Both study CFs have Shorea robusta Gaertn. (local name: Sal) as dominant tree. Other associated tree species are Terminalia bellirica (Gaertn.) Roxb. (Barro), Dalbergia sissoo DC. (Sissoo), and Cassia fistula L. (Rajbriksha). Common shrub species include Colebrookea oppositifolia Sm. (Dhursil), Rauvolfia serpentina (L.) Benth. ex Kurz (Sarpaganda), and Pogostemon benghalensis (Burm.f.) Kuntze (Rudhilo). Animals like Prionailurus viverrinus Bennett (Jungle cat), Hystrix indica Kerr (Porcupine), Macaca mulatta Zimmermann (Rhesus), Corvus splendens Vieillot (House crow), and Python molurus Linnaeus (Python) are present in the study area (DCFUG 2007, SCFUG 2007).

\section{Vegetation sampling}

Reconnaissance survey of the study forests was done in June 2016. Forest boundaries were marked with the help of global positioning system (GPS, Garmin). Based on the canopy cover, there were three microhabitats present in the study forests: canopy, canopy gap, and Edge. The "canopy" is the core interior area of forest with tree canopy $>80 \%$; "canopy gap" represents the open area inside the forest formed after death or felling of trees or due to recurrent fire and grazing in the past that prevented tree regeneration; and "edge" is the margin of forest with adjacent settlement and road. These three microhabitats were represented proportionately during sampling. Altogether, 100 plots (50 plots each in Sundari and 


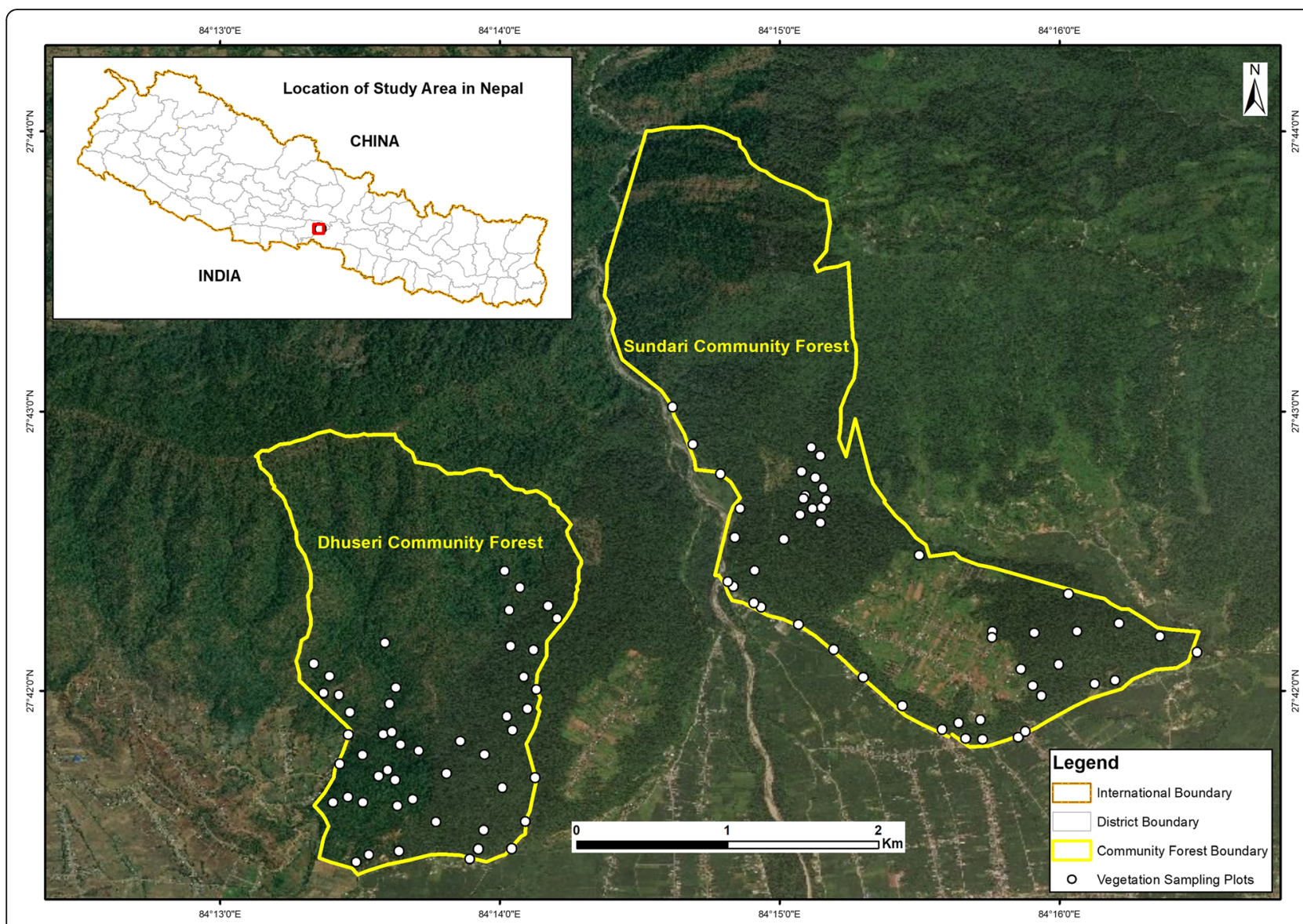

Fig. 1 Google Earth Map showing location of vegetation sample plots in Sundari (right) and Dhuseri (left) Community Forests

Dhuseri CFs) of $10 \mathrm{~m}$ radius were sampled by systematic sampling method with 51 plots in canopy, 28 plots in edge, and 21 plots in gap. In each plot, diameter of trees at breast height $(\mathrm{DBH}, 130 \mathrm{~cm})$ was measured with the help of measuring tape. The IAPS present in each plot were recorded. A checklist of 25 IAPS of Nepal reported by Shrestha (2016) was used for recording IAPS. Tree canopy cover as well as the cover of individual IAPS were estimated visually following cover class method of Daubenmire (1959). According to this method, cover was designated to one of the following six cover classes: $1=<5 \%$ cover, $2=5-25 \%, 3=25-50 \%, 4=50-75 \%, 5$ $=75-95 \%$, and $6=95-100 \%$.

\section{Data analysis}

Field data were used to calculate frequency, cover, and species richness of IAPS, tree basal area, and tree canopy cover. The frequency (\%) of each IAPS was calculated separately for each study forest as the percentage of plots (circular plot of $10 \mathrm{~m}$ radius) in which the species occurred (Zobel et al. 1987). The IAPS richness was measured as the number of IAPS recorded in each sampling plot. Cover class of each IAPS in each plot was converted into mid value of cover (e.g. $2.5 \%$ for cover class $1,15 \%$ for class 2 ). The mid values of the individual IAPS present in each plot were summed to get the combined cover of IAPS in each plot. Mean cover of each IAPS in canopy, canopy gap, and edge were also calculated. Basal area of each individual tree having $\mathrm{DBH} \geq 5$ $\mathrm{cm}$ was calculated. The basal area of all the individual trees in each plot, irrespective of the species identity, was summed to get tree basal area of a plot. Tree canopy cover in each plot was calculated in the same way as it was done for IAPS.

Cover and species richness of IAPS were compared among three microhabitats: canopy, canopy gap, and edge. The data did not meet the assumptions of normality and homoscedasticity. Therefore, cover and species richness were compared by non-parametric tests such as Kruskal-Wallis followed by Mann-Whitney $U$ tests in Statistical Package for Social Science (SPSS) version 20.0 (Armonk 2011). Furthermore, IAPS richness and IAPS cover were considered response variables whereas tree canopy and tree basal area were considered predictor variables using generalized linear model, Poisson family to model proportion, and count responses. Over 
dispersion was checked using residual deviance and degree of freedom. We used quasipoisson error instead of poisson error structure to account the over dispersion. For example, in the case of IAPS richness model, the over dispersion coefficient was found 1.9 and in canopy cover model the coefficient was found 21.8. These statistical analyses were conducted using $\mathrm{R}$ (version 3.3.2) ( $\mathrm{R}$ Development Core Team 2016), over dispersion was checked by performance (Lüdecke et al. 2020), and package ggplot2 (Wickham 2016) was used for data visualization.

\section{Results}

\section{Diversity and abundance of IAPS}

Altogether, 14 IAPS were recorded from the study forests (Fig. 2). There were 13 IAPS in Sundari CF and 12 in Dhuseri CF. Eleven species were common to both CFs but Mikania micrantha and Xanthium strumarium were recorded only in Sundari CF; and Parthenium hysterophorus was found only in Dhuseri CF. Chromolaena odorata was the most frequent IAPS which was found in nearly half of the plots in both forests. Other frequent IAPS were Spermacoce alata and Ageratum houstonianum. Lantana camara was frequent (28\%) in Sundari CF but rare (2\%) in in Dhuseri CF (Fig. 2).

\section{IAPS richness and cover}

The IAPS richness and cover were significantly higher at forest edge and gap than at the plots in canopy (Fig. 3). Species richness of IAPS at edge and gap was 6.5 and 5.3 times higher, respectively, than in canopy. Similarly, IAPS cover at edge and gap was 10.2 and 11.4 times higher than in canopy. All but one species had the highest cover either at canopy gap or forest edge (Table 1).
Dash (-) represents the absence of species. Data in bold face represents the highest value among three microhabitats

Species richness of IAPS declined significantly with increasing tree canopy cover and basal area (Fig. 4). Similarly, the cover of IAPS also declined with increasing tree canopy cover and basal area (Fig. 4). Among the two predictor variables considered in this study, tree canopy was found to have stronger negative effect on IAPS species richness and cover than that tree basal had (higher values of R for Tree canopy, Fig. 4).

\section{Discussion}

\section{Diversity of invasive alien plant species}

The number of invasive alien plant species (IAPS) recorded in two community managed forests (CF) (14 species) accounts $54 \%$ of the 26 species of IAPS reported from Nepal (Shrestha 2019). The number of IAPS varies with the extent of geographic area covered and the climatic conditions. For example, 14 IAPS were reported from Parsa National Park (area $627 \mathrm{~km}^{2}$ ) located in central Nepal (Chaudhary et al. 2020) and 12 IAPS from Bardiya National Park $\left(968 \mathrm{~km}^{2}\right)$ in western Nepal (Bhatta 2019). Physiographically, both these parks extends in Tarai and Siwalik regions. Area covered in the present study $\left(\mathrm{ca} .8 \mathrm{~km}^{2}\right)$ is far less than the two national parks mentioned above. Even then, the number of IAPS were nearly equal, suggesting that probability of IAPS invasion is higher in CFs than in national parks located in the same climatic and physiographic region. In general, the number of invasive alien species is expected to be low in protected areas such as the national parks due to buffering effects of the park boundary to the dispersal of invasive alien species (Foxcroft et al. 2011), whereas such buffering system is virtually absent in regions outside protected areas, leading to high probability of the

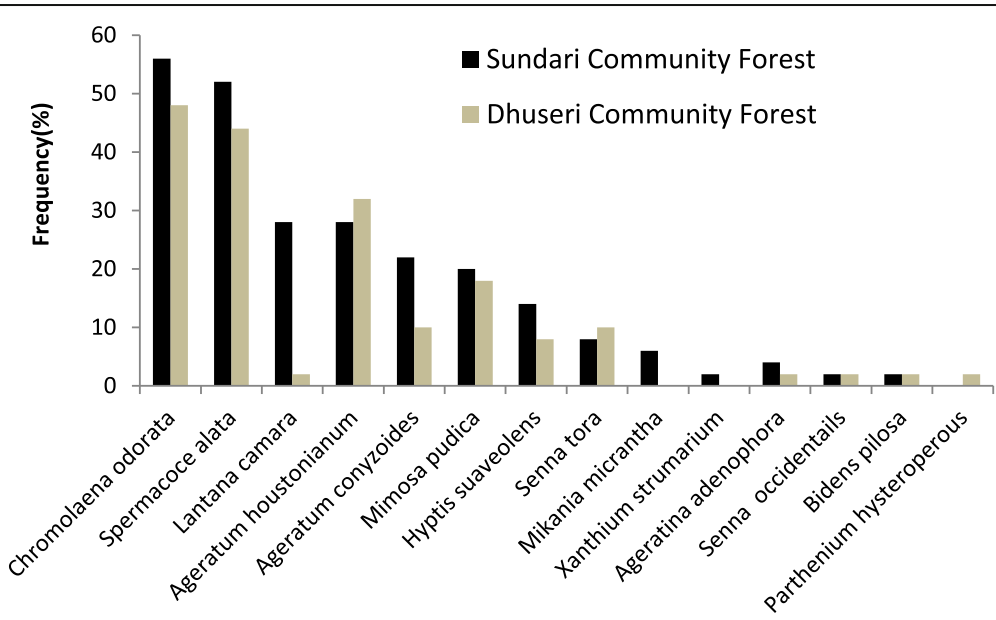

Fig. 2 Frequency of the invasive alien plant species in Sundari and Dhuseri Community Forests 

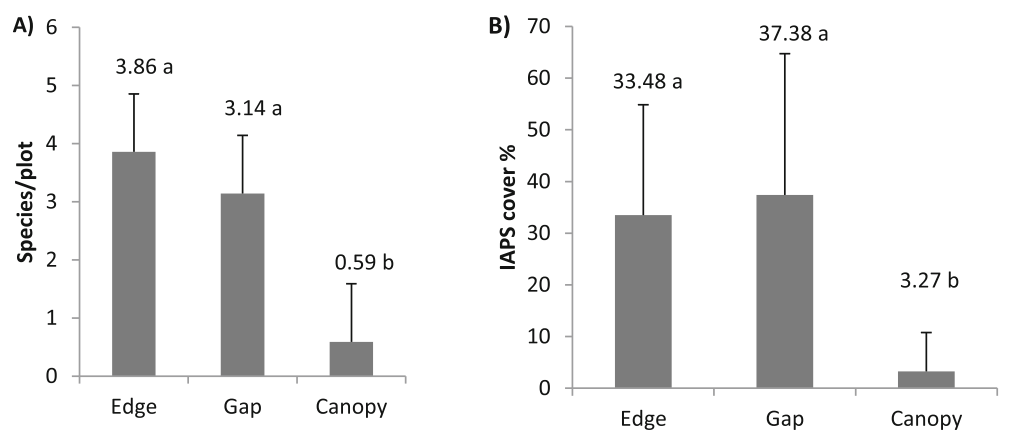

Fig. 3 Invasive alien plant species (IAPS) richness (a) and cover (b) across microhabitats. The values above the bar followed by the same alphabet are not significantly different $(p<0.05)$

occurrence of more IAPS. In Kailash Sacred Landscape Nepal (KSL-N; area 13,289 $\mathrm{km}^{2}$ ) which extends in four mountain districts of north-western Nepal, Shrestha et al. (2018) reported sixteen IAPS. The number of IAPS present in two CFs of the present study was two species less than the number of IAPS reported in the KSL-N though the present study area is very small as compared to KSL-N. It apparently indicates that there is high number of IAPS in lowlands of Nepal than in mountain landscapes. In another landscape Chitwan-Annapurna Landscape (area 32,090 $\mathrm{km}^{2}$ ), which extends from Tarai to high Himalayan regions in central Nepal, 23 IAPS were recorded (Siwakoti et al. 2016).

Three of the IAPS (Chromolaena odorata, Lantana camara and Mikania micrantha) found in the present study area are among 100 of the world's worst invasive alien species (Lowe et al. 2002). Among them, Chromolaena odorata was the most frequently occurring IAPS in both forests with this species present in nearly half of the plots sampled. It suggests that the species is widespread in the landscape surrounding the present study area and it might have arrived there $>30$ years ago when the forests were heavily degraded, i.e., before local communities started forest conservation. This is one of the common IAPS in Tarai, Siwalik, and Mid Hills of eastern and central Nepal (Tiwari et al. 2005) and globally in tropical and subtropical regions of Asia, Africa, and Oceania (Zachariades et al. 2009). Other two species were relatively less common with $M$. micrantha entirely absent in Dhuseri CF, suggesting that these two species were at the early stage of invasions. Since these two species are also notoriously invasive in other parts of Nepal (Tiwari et al. 2005) and elsewhere in the world (Lowe et al. 2002), their rapid spread to a larger area shortly is very likely. Rapid management responses can contain these small populations and prevent further spread. A systematic manual cutting through participatory approaches could be an effective measure to control IAPS,

Table 1 Mean cover of invasive alien plant species (IAPS) at three microhabitats

\begin{tabular}{|c|c|c|c|}
\hline \multirow[t]{2}{*}{ Name of invasive alien plant species } & \multicolumn{3}{|c|}{ Cover $(\%)$} \\
\hline & Canopy & Canopy gap & Edge \\
\hline Ageratina adenophora (Spreng.) R.King and H.Rob. & 0.20 & 0.56 & - \\
\hline Ageratum conyzoides $\mathrm{L}$. & 0.36 & 1.11 & 1.61 \\
\hline Ageratum houstonianum Mill. & 1.75 & 2.70 & 1.37 \\
\hline Bidens pilosa $\mathrm{L}$. & - & 1.59 & 0.65 \\
\hline Chromolaena odorata (L.) R. King and H. Rob. & 5.38 & 7.14 & 6.87 \\
\hline Hyptis suaveolens (L.) Poit. & 0.57 & 1.98 & 1.07 \\
\hline Lantana camara L. & 1.23 & 4.05 & 2.83 \\
\hline Mikania micrantha Kunth & 0.03 & 1.27 & 1.04 \\
\hline Mimosa pudica L. & 0.51 & 1.15 & 1.37 \\
\hline Parthenium hysteroperous L. & 0.03 & - & - \\
\hline Senna occidentalis (L.)Link & 0.02 & 0.52 & 0.03 \\
\hline Senna tora (L.)Roxb. & 0.24 & - & 0.83 \\
\hline Spermacoce alata Aubl. & 4.26 & 6.75 & 6.87 \\
\hline Xanthium strumarium L. & - & 2.02 & - \\
\hline
\end{tabular}



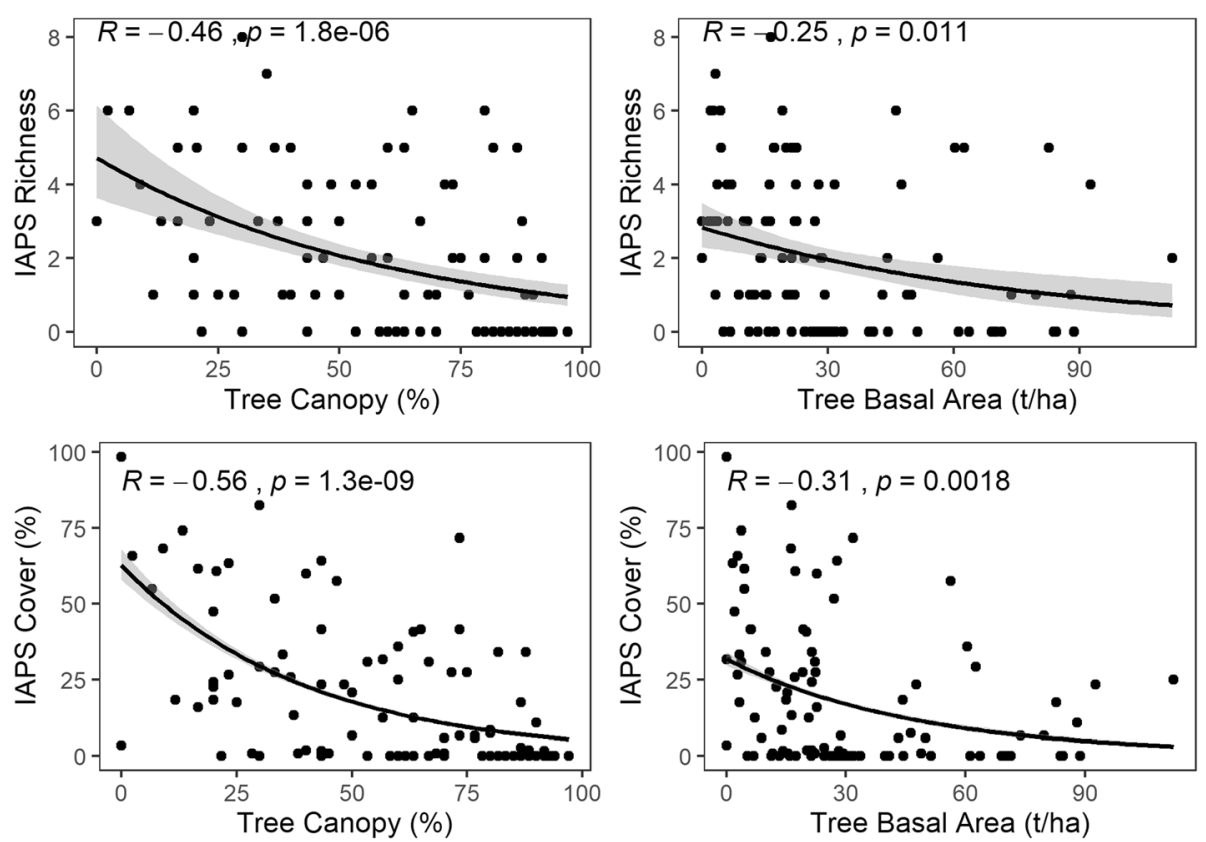

Fig. 4 Variation of invasive alien plant species (IAPS) richness (\#species/plot) with tree canopy and basal area as well as the IAPS cover with tree canopy and basal area. The fitted lines were based on the generalized linear model. The total number of sample plots was 100

particularly when population size is small (Rai et al. 2012). Manual uprooting followed by weeding of $L$. camara seeding could also be effective in eradicating small populations of this weed (Prasad et al. 2018). If sustained effort is made for few years, local eradication of these two species from the study forests would be possible. A combination of physical and chemical control methods can be effective for eradication of such small populations (Wittenberg and Cock 2001). However, extra precaution is needed for chemical method because it is not environmentally friendly and may not be easily accepted by public (Bremner et al. 2007).

\section{Variation of IAPS richness and abundance}

High tree canopy cover reduces the amount of light available on the ground surface which makes the habitat less favorable for the growth and reproduction of most IAPS (Baret et al. 2008). Such condition reduces the probability of infestation by IAPS and their colonization in forest ecosystem (Hartman et al. 2008). In the study area too, IAPS richness and cover decreased with increasing tree canopy cover and basal area (Fig. 3 and 4). Several other studies also have shown a decline in the abundance or species richness of IAPS with increasing canopy cover (McNab et al. 2002; Norbu 2004). The number of IAPS found in the interior of the forest with high tree canopy was lower than at forest edge and gap (Fig. 3). Though some IAPS were present in all three microhabitats that we studied, their covers were the lowest in the canopy plots (Table 1). Sunlight quantity, positively correlated with gap size, has been found to be one of the most important variables in expansion of IAPS in forest gaps. The forest edges may facilitate species' establishment and the flow of propagules. It may trap airborne propagules of IAPS and facilitate invasion (Joshi et al. 2015).

Several authors have suggested that forest sites with more edge and more gaps should be more likely to contain high number of IAPS (Matlack 1994; Baret et al. 2008). Colonization by IAPS is higher in forest edge and gap; they germinate and grow more rapidly in gap microhabitat within forest than in microhabitat with a closed canopy (McNab et al. 2002). Distribution of these weeds may also be localized in relation to edge and gaps resulting from disturbances such as tree falls, humanmade trails, and illicit felling (Joshi et al. 2015). Edge and gap formation generates considerable changes in the distribution and availability of environmental resources (Lockwood et al. 2005). Although, gap dynamics in natural forests have been studied, applications of gap dynamics to forestry practice in relation to IAPS management are limited (Mavimbela et al. 2018). Increase in canopy and closure of canopy gaps in the study forests after community management might have prevented establishment of new IAPS and suppressed the growth of previously established IAPS, particularly Chromolaena odorata as reported by local people. The observation made by the local people in the present study area is also supported by a research conducted in South Africa, where density and seed production of $C$. odorata 
was very low in shade (equivalent to canopy plots) compared to open sites (Witkowski and Wilson 2001). Therefore, suppressed growth of IAPS is the benefit of community forestry program of Nepal which has not been recognized and appreciated. However, additional studies is need covering large areas to test the generality of this assertion. Most of the IAPS establish first near the forest edges with their greater growth (Vargas et al. 2013). It was highly likely that the IAPS currently present in the study forests showed up first in forest edge and subsequently spread into forest interior. This assertion is supported by current distribution of Mikania micrantha in Sundari CF, where it was at initial stage of invasion and limited mainly at the forest edge and those gaps located near the forest edge. Given the high level of forest fragmentation and human disturbances, forest edges and gaps may always provide suitable habitats for IAPS to establish. Therefore, such microhabitats should be monitored regularly as a part of integrated IAPS management in community forests for the possible arrival of new IAPS.

\section{Conclusions and management implications}

We showed that IAPS cover and richness in the forests declined with increasing tree canopy, suggesting that management intervention in the degraded forests leading to canopy closure can suppress IAPS growth. These results have direct implications for the management of IAPS in forests of Nepal. Ecosystem based management of IAPS, i.e., prevention and control of IAPS though proper management of habitat/ecosystem, has been increasingly felt necessary as the number of IAPS and the areas of natural ecosystems that they have invaded are continuously increasing (Guo et al. 2018). Thousands of small to large patches of forests in Nepal are being managed by local communities, and, as a result of their management, the ecological conditions of forests have improved substantially in terms of vegetation cover, tree stocking, ecosystem services, and biodiversity conservation (Shrestha et al. 2010; Thapa-Magar and Shrestha 2015, Oldekop et al. 2019). Results of this study suggests that these participatory forest managements might have also helped to prevent and control many IAPS. To the best of our knowledge, this ecological benefit has not been acknowledged in scientific (e.g., Shrestha et al. 2010) and policy documents (e.g., MFSC 2014). Paradoxically, neither the local communities have been made well aware of the potential harms of IAPS by government and nongovernmental organizations, nor the IAPS management has been adequately included in forest operational plans-the guiding document for forest management (Shrestha et al. 2019). Recognition of
IAPS prevention and control as ecological benefits of participatory forest management in policy documents, integration of IAPS management in the operational plans of the CFs, and making communities aware of the potential harms of IAPS to environment and livelihood will improve community participation for IAPS management and restore ecosystem services of the forests in Nepal and elsewhere with similar bioclimatic and socio-economic conditions.

\section{Abbreviations \\ CF: Community forest; DCFUG: Dhuseri Community Forest Users' Group; GLM: Generalized linear model; IAPS: Invasive alien plant species; KSL- \\ N: Kailash Sacred Landscape Nepal; MFSC: Ministry of Forest and Soil Conservation; SCFUG: Sundari Community Forest Users' Group}

\section{Acknowledgements}

We are thankful to Dhuseri and Sudari Community Forest User's Groups for granting permission to sample the forests and other logistic supports. We thank Bidhya Shrestha, Chetmani Chaudhary, Pristi Dongol, Hira Shova Shrestha, Sanjeev Bhandari, Rabindra Bhattarai, Uma Panta, and Shova Khaniya for their helps during field work. We appreciate the helps from Prakash Aryal (Goldengate College, Kathmandu) for data analysis and Basanti Kumpakha (National Trust for Nature Conservation) for preparation of study area map.

\section{Authors' contributions}

BBS conceptualized research and designed the study, supervised the research, and reviewed the manuscript; LK collected and analyzed the field data, and prepared the first draft the manuscript. The author(s) read and approved the final manuscript.

\section{Authors' information}

Laximi Khaniya completed her MSc in Biodiversity and Environmental Management from the Central Department of Botany, Tribhuvan University, Kathmandu, Nepal. Her research interests include biological invasions, forest management, and mountain ecology. Currently, she is working as freelancer environmental consultant

Bharat Babu Shrestha, PhD, is an Associate Professor at the Central Department of Botany,

Tribhuvan University, Kathmandu, Nepal, with research interests on biological invasions, forest ecology, and plant adaptation along environmental

gradients in mountains. He is currently involved as Lead Author in thematic Assessment on Invasive Alien Species which is being commissioned by the Intergovernmental Science-Policy Platform for Biodiversity and Ecosystem Services (IPBES).

\section{Funding}

This research was supported by the Science Research Program through the National Trust

for Nature Conservation (NTNC), Kathmandu, Nepal.

\section{Availability of data and materials}

All data involved in this study are provided by the authors upon request.

Ethics approval and consent to participate

Not applicable

\section{Consent for publication \\ Not applicable.}

\section{Competing interests}

All authors declare that they have no competing interests.

Received: 25 April 2020 Accepted: 11 June 2020

Published online: 18 June 2020

References

Armonk NY: IBM Corp. IBM SPSS Statistics for Windows, Version 20.0. 2011. 
Baret S, Cournac B, Edwards CP, Strasberg D. Effects of canopy gap size on recruitment and invasion of the non-indigenous Rubus alceifolius in lowland tropical rain forest of Re 'union. J Trop Ecol. 2008;24:337-45.

Belnap J, Phillips SL, Sherrod SK, Moldenke A. Soil biota can change after exotic plant invasion: does this affect ecosystem processes? Ecology. 2005;86:300717.

Bhatta S. Distribution Mapping and Impact Assessment of Invasive Alien Plant Species in Bardia National Park, Western Nepal [MSc thesis]. Kathmandu, Nepal: Central Department of Botany, Tribhuvan University; 2019.

Bremner A, Park K. Public attitudes to the management of invasive non-native species in Scotland. Biol Conserv. 2007;139:306-14.

Burnham KM, Lee TD. Canopy gaps facilitate establishment, growth, and reproduction of invasive Frangula alnus in a Tsuga canadensis dominated forest. Biol Invasions. 2010;12:1509-20.

Chaudhary R, Shrestha BB, Thapa H, Siwakoti M. Status and impacts of invasive alien plant species in Parsa National Park, central Nepal. Banko Janakari. 2020 30(1):21-31.

Daubenmire R. A Canopy-coverage method of vegetational analysis. Northwest Sci. 1959:33:43-64.

DCFUG. Constitution of Dhuseri Community Forest User Group [Nepali]. Nawalpur, Nepal: Dhuseri Community Forest User Group (DCFUG); 2007.

Ehrenfeld JG. Effects of exotic plant invasions on soil nutrient cycling processes. Ecosystems. 2003;6:503-23.

Foxcroft LC, Jarošík V, Pyšek P, Richardson DM, Rouget M. Protected-area boundaries as filters of plant invasions. Conservation Biology. 2011;25:400-5.

Funk JL. The physiology of invasive plants in low resource environments. Conserv Physiol. 2013;1:1-16.

Guo Q, Brockway DG, Larson DL, Wang D, Ren H. Improving ecological restoration to curb biotic invasion-a practical guide. Invasive Plant Sci Manag. 2018;11:163-74.

Hartman KM, McCarthy BC. Changes in forest structure and species composition following invasion by a non-indigenous shrub, Amur honeysuckle (Lonicer amaackii). J Torrey Bot Soc. 2008;135:245-59.

Joshi AA, Mudappa D, Shankar TR. Invasive alien species in relation to edges and forest structure in tropical rainforest fragments of the Western Ghats. Trop Ecol. 2015;56:233-44.

Lockwood JL, Cassey P, Blackburn T. The role of propagule pressure in explaining species invasions. Trends Ecol Evol. 2005;20:223-5.

Lowe S, Browne M, Boudjelas S, Poorter DM. 100 of the World's Worst Invasive Alien Species. A selection from the Global Invasive Species Database. Auckland, New Zealand: The Invasive Species Specialist Group (ISSG); 2002.

Lüdecke D, Makowski D, Waggoner P, Patil I. Performance: assessment of regression models performance. $R$ package version 0.4.5. https://CRAN.Rproject.org/package=performance. 2020.

Martin PH, Canham CD, Marks PL. Why forests appear resistant to exotic plant invasions: intentional introductions stand dynamics, and the role of shade tolerance. Front Ecol Environ. 2009;7:142-9.

Matlack GR. Vegetation dynamics of the forest edge-trends in space and successional time. J Ecol. 1994;82:113-23.

Mavimbela LZ, Sieben EJJ, Proches S. Invasive alien plant species, fragmentation and scale effects on urban forest community composition in Durban. South Africa. New Zeal J For Sci. 2018:48:19. https://doi.org/10.1186/s40490-0180124-8.

McNab WH, Loftis DL. Probability of occurrence and habitat features for oriental bittersweet in an oak forest in the sourthern Appalachian Mountains. USA. Forest Ecol Manag. 2002;155:45-54.

MFSC. Nepal National Biodiversity Strategy and Action Plan 2014-2020. Kathmandu, Nepal: Ministry of Forest and Soil Conservation (MFSC); 2014.

Minden V, Jacobi J, Porembski S, Boehmer $\mathrm{H}$. Effects of invasive alien kahili ginger (Hedy chium gardnerianum) on native plant species regeneration in a Hawaiian rainforest. Appl Veg Sci. 2010;13:5-14.

Norbu N. Invasion Success of Chromolaena odorata in the Tarai of Nepal [MSc thesis]. International Institute for Geo-information Science and Earth Observation: Enschede, The Netherlands; 2004.

Oldekop JA, Sims KR, Karna BK, Whittingham MJ, Agrawal A. Reductions in deforestation and poverty from decentralized forest management in Nepal. Nature Sustainability. 2019;2:421-8.

Parendes LA, Jones JA. Role of light availability and dispersal in exotic plant invasion along roads and streams in the H.J. Andrews Experimental Forest, Oregon. Conserv Biol. 2000;14:64-75.
Prasad A, Ratnam J, Sankaran M. Rainfall and removal method influence eradication success for Lantana camara. Biol Invasions. 2018:20:3399-407.

R Development Core Team. R: A Language and environment for Statistical Computing. R Foundation for Statistical Computing Vienna. 2016. Available at: http://www.R-project.org/.

Rai RK, Scarborough H, Subedi N, Lamichhane BR. Invasive plants - do they devastate or diversify rural livelihoods? Rural farmers' perception of three invasive plants in Nepal. Nat Conserv. 2012;20:170-6.

SCFUG. Constitution of Sundari Community Forest User Group [Nepali] Nawalpur, Nepal: Sundari Community Forest User Group (SCFUG); 2007

Shrestha BB, Invasive alien plant species in Nepal. In: Jha PK, Siwakoti M, Rajbhandary S, editors. Frontiers of botany. Kathmandu: Central Department of Botany, Tribhuvan University; 2016. p. 269-284.

Shrestha BB, Management of invasive alien plant species in Nepal: current practices and future prospects. In: Garkoti SC, van Bloem S, Fule PZ, RL Semwal, editors. Tropical ecosystems: structure, functions and global change. Singapore: Springer Nature; 2019. p. 45-68.

Shrestha BB, Joshi-Rijal S, Bisht N, Yi S, Kotru R, Chaudhary RP, Wu N, Inventory and impact assessment of invasive alien plant species in Kailash Sacred Landscape. ICIMOD Working Paper 2018/2. Kathmandu, Nepal: International Center for Integrated Mountain Development (ICIMOD); 2018.

Shrestha BB, Shrestha UB, Sharma KP, Thapa-Parajuli RB, Devkota A, Siwakoti M. Community perception and prioritization of invasive alien plants in ChitwanAnnapurna Landscape. Nepal. J Environ Manage. 2019;229:38-47.

Shrestha UB, Shrestha BB, Shrestha S. Biodiversity conservation in community forests of Nepal: Rhetoric and reality. International J Biodivers Conserv. 2010; 2:98-104.

Siwakoti M, Shrestha BB, Devkota A, Shrestha UB, Parajuli RBT, Sharma KP. Assessment of the effects of climate change on the distribution of invasive alien species in Nepal. In: Bhuju DR, Claughlin KM, Sijapati J, Devkota BD, Shrestha N, Ghimire GP, Neupane PK, editors. Building knowledge for climate resilience in Nepal: research briefs. Lalitpur, Nepal: Nepal Academy of Science and Technology; 2016. p. 5-8.

Thapa-Magar KB, Shrestha BB. Carbon stock in community managed hill sal (Shorea robusta) forests of central Nepal. J Sustain Forest. 2015;34(5):483-501.

Tiwari S, Siwakoti M, Adhikari B, Subedi K. An inventory and assessment of invasive alien plant species of Nepal. IUCN- The World Conservation Union, Nepal: Kathmandu, Nepal; 2005.

Vargas R, Gartner S, Alvarez M, Hagen E, Reif A. Does restoration help the Conservation of the threatened forest of Robinson Crusoe Island? The impact of forest gap attributes on endemic plant species richness and exotic invasions. Biodivers Conserv. 2013;22:1283-300.

Wickham H. ggplot2: Elegant graphics for data analysis. New York: SpringerVerlag; 2016.

Witkowski ETF, Wilson M. Changes in density, biomass, seed production and soil seed banks of the non-native invasive plant, Chromolaena odorata, along a 15 year chronosequence. Plant Ecology. 2001;152:13-27.

Wittenberg R, Cock MJ, editors. Invasive alien species: a toolkit of best prevention and management practices. Wallingford, Oxon, UK: CAB International; 2001.

Yamamoto SI. Forest gap dynamics and tree regeneration. J Forest Res. 2000;5: 223-9.

Zachariades C, Day M, Muniappan R, Reddy GVP. Chromolaena odorata (L.) King and Robinson (Asteraceae). In: Muniappan R, Reddy GVP, Raman A, editors. Biological control of tropical weeds using arthropods. Cambridge, UK: Cambridge University Press; 2009. p. 130-162.

Zobel DB, Jha PK, Behan MJ, Yadav UKR. A Practical Manual for Ecology. Ratna Pustak Distributors: Kathmandu, Nepal; 1987.

\section{Publisher's Note}

Springer Nature remains neutral with regard to jurisdictional claims in published maps and institutional affiliations. 